\title{
Two Distinct Kimberlite Types at the Churchill Diamond Project
}

\author{
Pamela Strand ${ }^{1}$, Anetta Banas' , Jennifer Burgess ${ }^{3}$, Mike Baumgartner ${ }^{4}$ \\ ${ }^{I}$ Shear Minerals Ltd., Edmonton, AB, Canada, \\ ${ }^{2}$ APEX Geoscience Ltd., Edmonton, AB, Canada, \\ ${ }^{3}$ Burgess Diamonds, Sechelt, BC, Canada, \\ ${ }^{4}$ Mineral Services Canada, North Vancouver, BC, Canada
}

\section{Introduction}

The Churchill Diamond Project is a new, continuously expanding kimberlite district that was discovered in 2003 by Shear Minerals Ltd. and partner Stornoway Diamond Corporation. To date 79 kimberlites have been discovered on the property, including 9 highly diamondiferous kimberlite dykes (Kahuna, PST, Notch, Jigsaw and smaller unnamed dykes). The project is located between the communities of Rankin Inlet and Chesterfield Inlet in Nunavut, Canada (Figure 1).

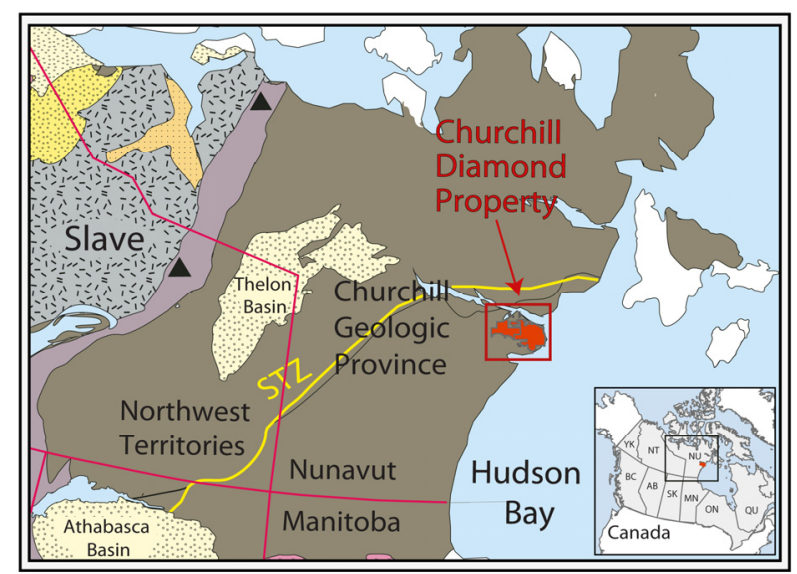

Figure 1: Location map. Modified after Berman et al., 2007.

\section{Geological Setting}

The property is underlain by rocks of the metamorphosed Archean Rankin Inlet group and surrounded by Archean metaplutonic rocks of the Churchill Structural Province of the Archean Canadian Shield (Figure 1; Hoffman, 1990).

The Quaternary geology of the region is dominated by glaciation associated with the Laurentide ice sheet flowing in a southeasterly direction (McMartin, 2000). Surficial deposits are dominated by till mounds with segregated glaciofluvial deposits found throughout the southern part of the property and marine reworked deposits along the Hudson Bay coast. Detailed knowledge of the Quaternary geology has been a fundamental part of the planning and execution of the till sampling exploration program and in understanding the results thereof (Strand et al., in press).

\section{Exploration History}

Through an extensive sampling program, completed between 2002 and 2007, over 10,000 till samples have been collected on the property. Abundant indicator minerals, including high-Cr peridotitic garnet, low-Cr eclogitic/pyroxenitic/megacryst garnet, chrome diopside, Mg-chromite, picro-ilmenite and olivine have been recovered. Confluences of high counts of indicator minerals resulted in the recognition of two main corridors of interest namely the Josephine River ('JR') and Sedna corridors (Figure 2). The high abundance of indicator minerals with favorable compositions - especially the presence of high-Cr subcalcic G10 pyropes - has driven exploration in the area.

The property has been extensively covered by regional and detailed airborne and ground geophysical surveys. Between 2003 and 2005, numerous geophysical targets were identified and the majority of those that were selected for drilling proved to be kimberlite pipes. However, these kimberlites had indicator mineral compositions which did not coincide with the high interest compositions recovered from the till samples and were either very weakly diamondiferous or barren of microdiamonds. In 2006, prospecting in areas with high interest garnet compositions led to the discovery of a second kimberlite type with similar high interest indicator mineral compositions to those recovered from till samples. Subsequently, field prospecting and drilling in 2006 and 2007 has uncovered 9 kimberlites with similar characteristics, all of which are highly diamondiferous. This has led to the delineation of twodistinct kimberlite types on the Churchill property: Type A and Type B each with discrete characteristics.

\section{Kimberlite Characterization}

Type A (low interest) kimberlites are characterized by strong magnetic signatures. They are fine grained with dominantly magmatic textures, contain rare to absent livine macrocrysts, and commonly contain large olivine phenocrysts (Figure 3). The Type A kimberlites contain low abundances of indicator minerals which are dominated by ilmenite and contain rare garnet. The garnets have compositional trends suggesting low diamond potential. Based on clinopyroxene xenocrysts a geothermal gradient of $\sim 40-41 \mathrm{~mW} / \mathrm{m}^{2}$ was modeled for the Type A kimberlites. They have emplacement o ages between 170 and 228 Ma. Seventy-one kimberlites (pipes and dykes) of this type have been discovered to date. 


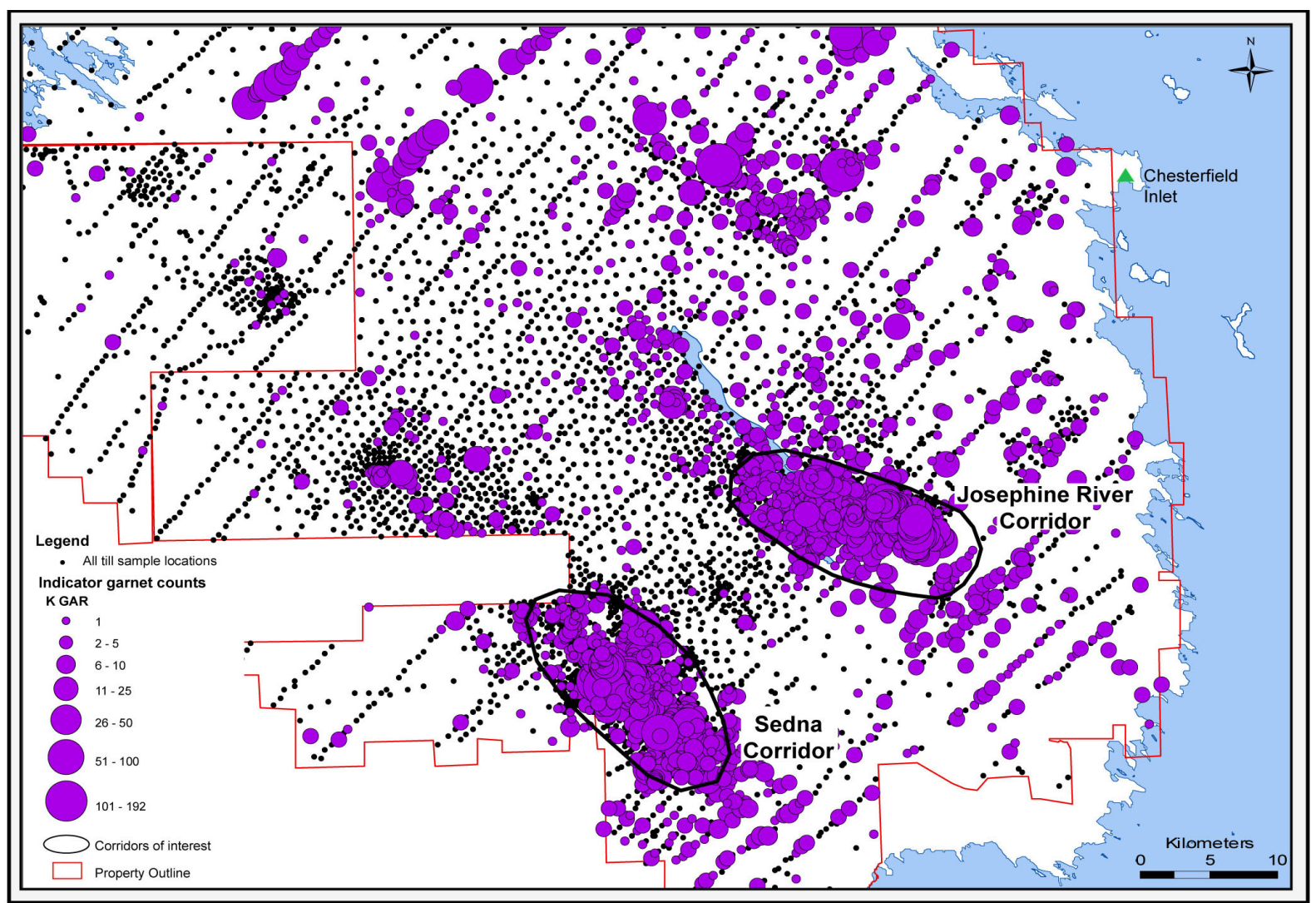

Figure 2: Distribution of abundant probe confirmed diamond indicator garnet counts delineating two main corridors of interest.

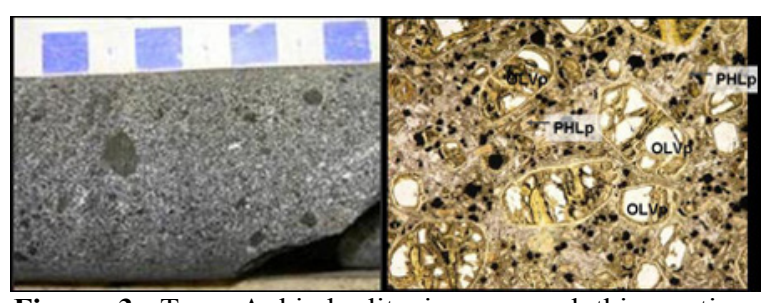

Figure 3: Type A kimberlite in core and thin section exhibiting common large olivine phenocrysts.

In contrast, Type $\mathrm{B}$ (high interest) kimberlites are characterized by subtle magnetic signatures. They are magmatic, medium to coarse-grained, and contain two generations of olivine, including abundant olivine macrocrysts (Figure 4). These kimberlites contain abundant indicator minerals with low ilmenite and high garnet counts, both showing prospective compositions. A lower geothermal gradient of $\sim 37 \mathrm{~mW} / \mathrm{m}^{2}$ has been calculated for these bodies. Two of the Type B dykes (Notch and Kahuna) have been dated and fall on an isochron age of $234 \mathrm{Ma}$. Nine Type B kimberlite dykes have been discovered to date.

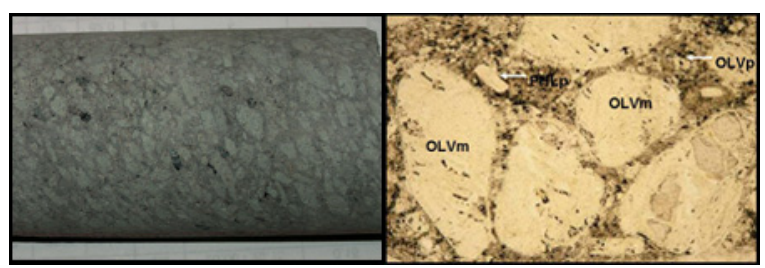

Figure 4: Type $\mathrm{B}$ kimberlite in core and thin section exhibiting common olivine macrocrysts, olivine phenocrysts and phlogopite phenocrysts.

\section{Contrasting Indicator Mineral Compositions}

Detailed analysis of the indicator mineral compositions was integral to the recognition that two types of kimberlites existed in this area. The initially discovered Type A kimberlites did not reflect the highly encouraging indicator mineral abundances and compositions found in many of the till samples $(>27 \%$ G10). The garnets recovered from the Type A kimberlites are characterised by high-Ca G9 compositions which are distinctly offset from the G9/G10 line (Figure 5; Gurney, 1984).

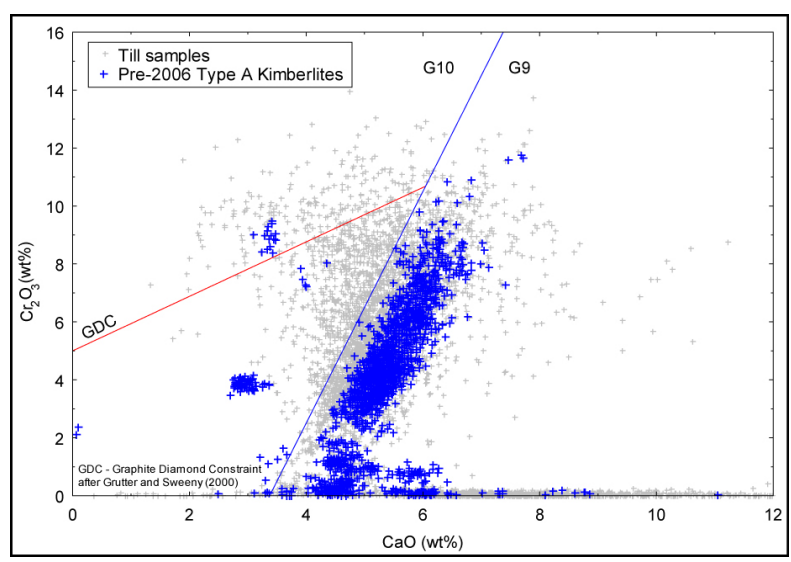

Figure 5: Contrasting garnet compositions from the till samples versus the Type A kimberlites.

In contrast to the Type A kimberlites, the Type B kimberlites show significant overlap with the high interest compositions recovered from the till samples. The garnets from Type B kimberlite are characterized 
by common Cr-rich G10 pyropes and low-Ca G9 pyropes which plot close to the G9/G10 line. These compositions have been associated with derivation from within the diamond stability field (Figure 6; Grütter and Menzies, 2003).

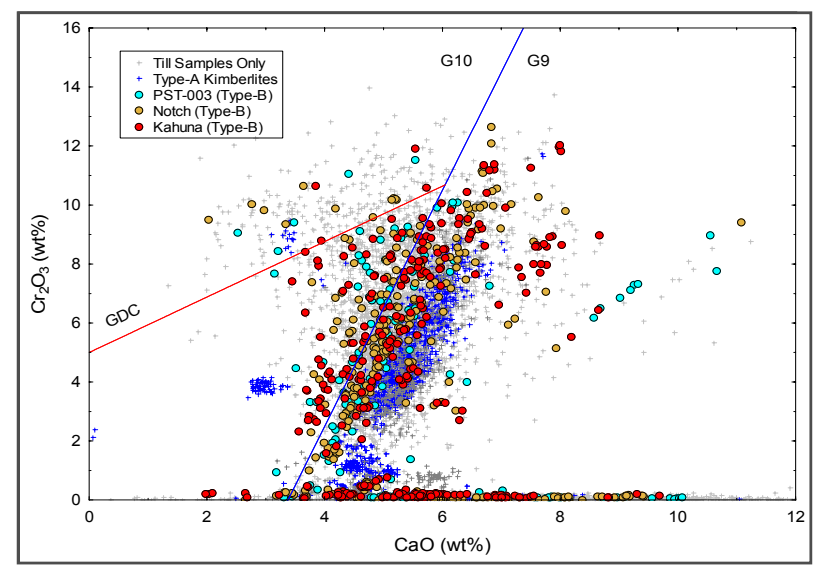

Figure 6: Contrasting pyrope compositions from the till samples versus the Type A and Type B kimberlites.

The presence of two distinct thermal regimes was first identified in temperature and pressure profiles established for the peridotitic garnets recovered from the till samples. The presence of "low" geotherm peridotitic garnets was key to the discovery of the first Type B kimberlites.

Comprehensive analysis of the oxides has also shown the presence of two ilmenite populations. Ilmenite associated with the high interest Type $\mathrm{B}$ kimberlite has higher $\mathrm{MgO}$ and $\mathrm{Cr}_{2} \mathrm{O}_{3}$ and lower $\mathrm{TiO}_{2}$ and $\mathrm{Al}_{2} \mathrm{O}_{3}$ than ilmenite from the low interest Type A bodies.

\section{Implications for Diamond content}

In accordance with their petrographic classification and indicator mineral compositions, the low interest kimberlites have negligible diamond contents whereas the high interest kimberlites are significantly diamondiferous. Grades obtained from mini-bulk sampling of the Type B kimberlites vary from $0.39 \mathrm{cpt}$ (carats per tonne) for Jigsaw to $2.04 \mathrm{cpt}$ for the PST kimberlite (Figure 7 ). The longest $(>6 \mathrm{~km})$ and widest

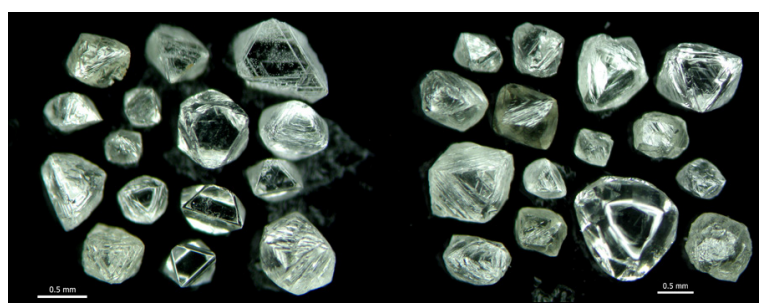

Figure 7: Diamonds from the Notch (left) and PST (right) kimberlite mini-bulk samples.

(up to $4 \mathrm{~m}$ ) of the Type B dykes, the Kahuna kimberlite, has a grade of 1.09 cpt. Drilling of certain Type B dykes in 2007 has returned $>150$ diamonds $/ \mathrm{kg}$ in microdiamond counts.

\section{Conclusions}

Diligent analysis of the abundance and compositions of indicator minerals in till samples has led to the discovery of two types of kimberlites on the Churchill Diamond Property. This has required looking beyond geophysical signatures to find highly diamondiferous kimberlites that are the source of the high interest mineral compositions recovered from the till samples. Many unsourced dispersions $(>25)$ containing high interest mineral compositions remain to be tested on the property.

\section{Acknowledgements}

This project would not be possible without the participation of many contributors: our partner Stornoway Diamond Corporation, and former partner BHP Billiton; the laboratories (incl. SRC \& Mineral Services) on whom we rely on for timely data; all our project crew and support staff that have dedicated large amounts of their time to be in the field, during good and bad weather; as well as Kit Campbell and Herman Grütter; finally all the shareholders that fund and support diamond exploration as it grows as one of the newest chapters in Canadian mining.

\section{References}

Grütter, H.S., Menzies, A., (2003), Mutually consistent classification schemes for mantle derived garnet and chromite, for use by diamond explorers. 8th Inetrnational Kimberlites Conference Extended Abstracts, 5p.

Grütter, H.S. and Sweeney, R.J., (2000) Tests and constraints on single-grain Cr-pyrope barometer models: some initial results. Program with Abstracts - Geological Association of Canada; Mineralogical Association of Canada: Joint Annual Meeting, vol.25, unpaginated

Gurney, J.J., (1984) A correlation between garnets and diamonds in kimberlite. In Kimberlite Occurrence and Origin: A basis for conceptual models in exploration, J.E. Glover and P.G. Harris (eds.) Geology Department and University Extension, University of Western Australia, Publication No.8, p.143-166.

Hoffman, P.F. (1990) Subdivisions of the Churchill Province and extent of the Trans-Hudson Orogen, in Lewry, J.F., and Stauffer, M.R., eds. The early Proterozoic TransHudson orogen of North America: Ottawa, Geol. Assoc. of Canada Spec. Paper 37, p. 15-39.

McMartin, I., (2000) Till composition across the Meliadine Trend, Rankin Inlet area, Kivalliq region, Nunavut; Geological Survey of Canada, Open File Report 3747.

Strand, P., Banas, A., Baumgartner, M., Burgess, J., (in press) Tracing Kimberlite Indicator Mineral Dispersal Trains: An example from the Churchill Diamond Project, Kivalliq region, Nunavut. In: Paulen, R. and McMartin, I., (eds) Application of Till and Stream Sediment Heavy mineral and Geochemical Methods to Mineral Exploration in Western and Northern Canada, GAC Short Course Notes 18, Geol. Assoc. of Canada 